\title{
A Preliminary Study for Cucurbita moschata Duchesne (Loche) Crop Production under the Hydroponic Dutch Bucket System
}

\section{Edwin F Vásquez ${ }^{1 *}$ and Damian A Vásquez}

${ }^{1}$ Programa de Agricultura en Ambiente Controlado, Peru

${ }^{2}$ Area de Investigación y Desarrollo, Asociación "Llacta Maki”, Jr. San Juan No 528, C.P. 06121, Cajamarca, Perú

\begin{abstract}
Introduction: "Loche" is a pre-Hispanic cucurbit crop highly appreciated in Peruvian cuisine. Produced in northern Peru possess a diverse set of environmental limiting factors for profitable production: Ambient temperature, $\mathrm{pH}$, irrigation, plagues and diseases; furthermore, Hydroponic crop production is being extensively applied for high value crops, favorable in "Loche" production case, these factors can be easily monitored and controlled under a soilless culture technology.
\end{abstract}

Objective: To establish "Loche" plants in the hydroponic Ductch bucket system.

Methods: Trials of cucurbit species were carried out in the Raft and Dutch bucket systems; upon positive results, "Loche" was tested in the Dutch Bucket system. Vegetative seeds consisting of 5-6 node-long vines were purchased in a local area and subjected to rooting procedures after which seedlings $(n=10)$ were transplanted to 51 Dutch Buckets for vegetative and reproductive growth. Leaves diameter was measured at $50 \mathrm{~cm}$ and $2 \mathrm{~m}$ and inter-nodal length at $50 \mathrm{~cm}, 120 \mathrm{~cm}$ and $2 \mathrm{~m}$ of height.

Results: Plants showed no sign of nutritional deficiency and their structures (long stems and bigger leaves diameter upwards the plant, $p<0.05$ ) resembled adaptations to a high temperature environment with constant water supply. Male flowers blossomed at 60 days of plants growth and no female flowers were observed.

Conclusion: "Loche" was successfully established in the hydroponic Dutch bucket system. No previous work in this field has been reported for this crop. However, further research is needed for the technique to be apply at a commercial level.

Keywords: "Loche"; "Loche de Lambayeque"; Hydroponic Technology; Dutch Bucket; Soilless agriculture

\section{Introduction}

"Loche" Cucurvita moschata Duchesne is a pre-Columbian squash, member of the Cucurbitaceae family. In Peruvian territory is commonly referred as "Loche" and lately "Loche de Lambayeque" [1], the last being a geographical reference given that the "Loche" production is focused in Lambayeque region, northern Peru which was the center for an ancient civilization called "The Moche" and whose population domesticated "Loche" squash as depicted in archaeological findings $[2,3]$.

Cucurbitaceae family is a major group with more than 100 genera and 800 Species among which some food-producing plants commonly referred as pumpkins and squashes are found $[4,5]$; lonely or racimic flowering structures of unisexual flowers are observed, distinctive in this group is that the five welded stamens form an axial sinander and inferior ovary for female flowers, fruits being penonide type; "Loche" is monoecious and $2 n=40$ [3]. Fruits of "Loche" have 10 loosely defined warty longitudinal ridges that are often a darker shade than the rest of the fruit and thus make the fruit subtly stripped, they start out light green but gradually turn to dark green with a glaucous waxy covering at maturity [6]. Recently, a comprehensive description of this squash was made, concluding that there had been domesticated two highly differentiated varieties of C. moschata Duchesne ("zapallo Loche", "zapallo criollo"): a small seedless flavorsome one (fruits $<1 \mathrm{~kg}$ ) and a big seed-producing less flavorish one (fruits $<2 \mathrm{~kg}>$ ), the last more extensively cultivated and whose fruits exceptionally reach $6 \mathrm{~kg}$ [7]. Commercially, fruits are classified in seven qualities from less than 650 g to above $2.2 \mathrm{~kg}[8]$.
"Loche de Lambayeque" is highly appreciated in Peruvian cuisine $[9,10]$, presumably due to a high content of umami flavor signaling molecules, its aroma and flavor are sui generis, being nutrition-driven consumption not systematically reported. Its production is regioncentered having been reported in different areas of north Peru $[6,8]$. Research on its agro-technology is limited despite its demand in the local and national markets. Moreover, literature is scarce and when present is not available to the grower due to the lack of diffusion programs. On this last remark, attempts to seed production through in vitro tissue culture [7], molecular characterization of regional varieties $[7,11,12]$ and food manufacturing [13] have been studied.

\section{Crop production}

Cucurbits (pumpkin and squash) crop production and management have been extensively studied and data reports different factors involved in profitable yields of $\mathrm{kg} / \mathrm{ha}$, as usually expressed. Among them: temperatures of $18^{\circ} \mathrm{C}-24^{\circ} \mathrm{C}$ and $20^{\circ} \mathrm{C}-35^{\circ} \mathrm{C}$; soil $\mathrm{pH}$ of 6.0-6.8 and 6.0-6.5; nutrient management including the enrichment

${ }^{*}$ Corresponding author: Edwin F Vásquez, Programa de Agricultura en Ambiente Controlado, Perú, Tel: 0051074 234542; E-mail: edfervas@gmail.com

Received November 06, 2017; Accepted November 27, 2017; Published December 04, 2017

Citation: Vásquez EF, Vásquez DA (2017) A Preliminary Study for Cucurbita moschata Duchesne (Loche) Crop Production under the Hydroponic Dutch Bucket System. Agrotechnology 6: 173. doi: 10.4172/2168-9881.1000173

Copyright: (c) 2017 Vásquez EF, et al. This is an open-access article distributed under the terms of the Creative Commons Attribution License, which permits unrestricted use, distribution, and reproduction in any medium, provided the original author and source are credited. 
with manures, compost, fish meal, bone meal and inorganic fertilizers; plague and disease control with cultural, chemical, biological, ethological techniques have been described; along with variable irrigation patterns [14-16]. Cucurbita moschata cultivars requirements are quite similar: Temperatures of $25^{\circ} \mathrm{C}-26^{\circ} \mathrm{C}$ optimum and limits of $18^{\circ} \mathrm{C}-32^{\circ} \mathrm{C}$, soil $\mathrm{pH}$ from $6.0-7.5$ and the other factors equally diverse as in the family group [17]; As for "Loche" squash: temperatures of $18^{\circ} \mathrm{C}-20^{\circ} \mathrm{C}, \mathrm{pH}$ of $5.5-7.5$, fertilization with organic, inorganic, solid and foliar fertilizers, applications of hormones to regulate flowering and irrigation with plague and disease managements also variable [8]. "Loche" is considered a "special" crop to be grown, meaning that environmental factors must be precisely controlled to obtain high yields, temperature known to be critical $[6-8,12]$.

On "Loche" production, soil and plant nutritional status, plague and disease management, irrigation, human and machine work force expenditure account for up to $80 \%$ of total budget [8]. An expensive crop whose permanence is only justified by high prices on the local market (5-10 times) and national market (up to 20 times) when compared to other edible cucurbits. Greenhouse techniques have been used to better control this parameter as for other cucurbits [18], whereas results are yet to be known, soilless agriculture in a controlled environment can be considered for this so-referred "special" squash.

\section{Hydroponic crop production}

Hydroponic agriculture is a soilless technique which has been used for millennia. Nowadays, it is used for home production, it has a market place for some vegetables and USA-NASA [19] and war submarines use this technology to feed their crew and most likely will be used when colonizing earth-like planets. Working with water (hydro=agua and ponos=work) would be a valid translation from Latin and it refers to the use of water as a phase to provide the plant with all nutrients transported by the root it requires for proper growth and development in a controlled environment; systems for such an objective are diverse: Static phase: Lettuce raft system and variations [20]; and flowing phase: Aeroponics (aero spring), Nutrient film technique (PVC pipe gardens), the auto pod and the Dutch bucket systems are the most currently used, variations for each cultivar are usually employed and for growing organically; In hydroponics crop production temperatures of air and soilless substrate, $\mathrm{pH}$, irrigation, plagues, diseases and irradiation intensity can be monitored and controlled unlike conventional agriculture; However, the initial investment is high and technical knowledge of basic principles is required thus only applied in some crops: Lettuce, tomato, carrot, pepper, potato, cabbage, cucumber among the most important economically [19,2123]. Hydroponic production for "Loche" has not been reported in literature. Nevertheless, the technique has been used to study rooting [24] and flowering [25] in other cucurbits. The current study focused on the establishment of Cucurbita moschata var. Duchesne "Loche" in the Dutch bucket system as an alternative for crop production.

\section{Material and Methods}

\section{Pilot trial in Cucurbit species}

As a proof of concept experiment, cucurbits: Ciclantera pedata "Caigua" and Cucurbita maxima Duchesne "Zapallo Macre" was tested in a modified raft [20] and with the Dutch bucket systems. The nutrient solution was the same in all treatments [26] and was prepared with soluble salts of the highest purity available in the local market, $\mathrm{pH}$ was measure only after preparation (6.0-6.5) and no further measurements were made. Regular changes of nutrient solution were made for the Dutch bucket experiments, ambient temperature was measure daily.
Both systems were successful for vegetative growth, however, a fixed volume of nutrient solution was difficult to calculate as for the raft system to be continued. In the Dutch bucket system, vegetative growth was allowed until the first appearance of female flowers (Figure 1) after which the plants were removed and "Loche" establishment was initiated.

\section{"Loche" establishment}

Sampling preparation: Cuts of 5-6 node-long vines were purchased in a local area, vines were taken from a stock of mother plants usually maintained by growers. A total of 60 cuts were selected based on the presence of adventitious root buds. They were subjected to rooting procedures in $1 / 2 x$ nutrient solution alone, under fluorescent light and with constant aeration for 7 days after which a first selection based on rooting took place. Afterwards, they were place in $1 \mathrm{~L}$ Dutch buckets and maintained under moderate sunlight for 7 days for a final selection based on infestation and diseases signs and symptoms.

Sampling transplanting: The 15 -day seedlings were placed in 51 Dutch buckets and placed under sunlight. Care was taken not to harm roots in this procedure and plans with phenolic roots were discarded. Both $1 \mathrm{~L}$ and $5 \mathrm{~L}$ Dutch buckets substrate consisted of $50 \%$ rice hulls $/ 50 \%$ volcanic stones [19] which was cleaned and sterilized before use.

Vegetative and reproductive phase: Vines $(n=10)$ were kept in a sunny environment (8-10 h/day), old leaves and tendrils were removed to allow a proper distribution and usage of nutrients. Vines were guided upwards using polyethylene ropes. Depending on the state of health of each plant 2-3 vines could grow. Leaves diameter at $50 \mathrm{~cm}$ and $2 \mathrm{~m}$ was recorded and stems intermodal length at $50 \mathrm{~cm}, 120 \mathrm{~cm}$ and $2 \mathrm{~m}$ were measured of the main vine. Vegetative growth was allowed until the appearance of female flowers. Temperature measurements were made daily. Roots were only observed at the end of the experiment. A pre-experimental study design was used andmeasurements were taken from the main vine.

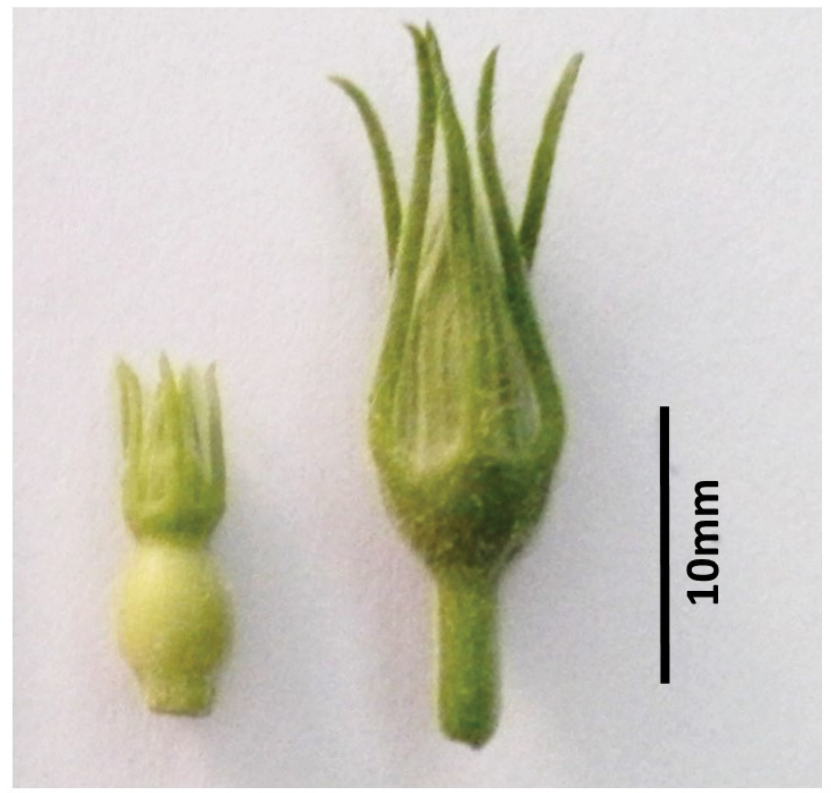

Figure 1: Flowering structures of Cucurbita maxima Duchesne "Zapallo Macre"grown in the Dutch Bucket system. Female flower (Left) and Male flower (Right). 
Statistical analysis: Descriptive statistics for vine length, T-test for mean differences of homoscedastic variance in leaf diameter and oneway ANOVA for inter-nodal stem length with Tukey post-hoc tests were performed using SPSS-19 software package [27].

\section{Results}

\section{Sampling and transplant}

Sampling spanned 15 days and $16 \%(\mathrm{n}=10)$ of total stems cuts were successfully transplanted $(\mathrm{n}=10 ; 69.8+-8.9 \mathrm{~cm}$ of height) and used for the next step; undesirable fungi (Fusarium sp.), bacteria (Phytophtora sp.), virus and white fly (Bemisia tabaci) signs and symptoms were identified during sampling, all of which were eliminated throughout the selections steps but viral symptoms which were observed as light and green mosaicism in healthy dark green leaves [28].

\section{Vegetative and reproductive phase}

Plants showed no sign of nutritional deficiency. Leaves diameter significantly increased upwards the plants $(50 \mathrm{~cm}=3.36 \pm 0.53 \mathrm{~cm}$ and $2 \mathrm{~m}=6.48 \pm 0.48 \mathrm{~cm}, \mathrm{p}<0.05$ ); Differences in stems node length were statistically different in the three height measurements $(50 \mathrm{~cm}=4.39 \pm$ $0.49 \mathrm{~cm}, 120 \mathrm{~cm}=7.26 \pm 0.58 \mathrm{~cm}$ and $2 \mathrm{~m}=11.81 \pm 0.89 \mathrm{~cm}, \mathrm{p}<0.05)$. Finally, flowering buds were observed on day 15 th after transplanting, flowering was observed only 30 days later (Figure 2) with plants average height of $225 \pm 0.25 \mathrm{~m}$. Female flower buds were not observed. The root system of plants was no phenolic, abundant and located in the base of the bucket where a reservoir of nutrient solution is secured by the adopted system. Temperatures ranged from $25^{\circ} \mathrm{C}-30^{\circ} \mathrm{C}$ given that experiments took place in summer 2015.

\section{Discussion}

Results indicate that "Loche" can be grown under hydroponic technology. However, if this technology is to be used, there are some challenges to be overcome to produce at a profitable level: Temperature regulation, seed production and female/male flowering ratio which is directly correlated to production.

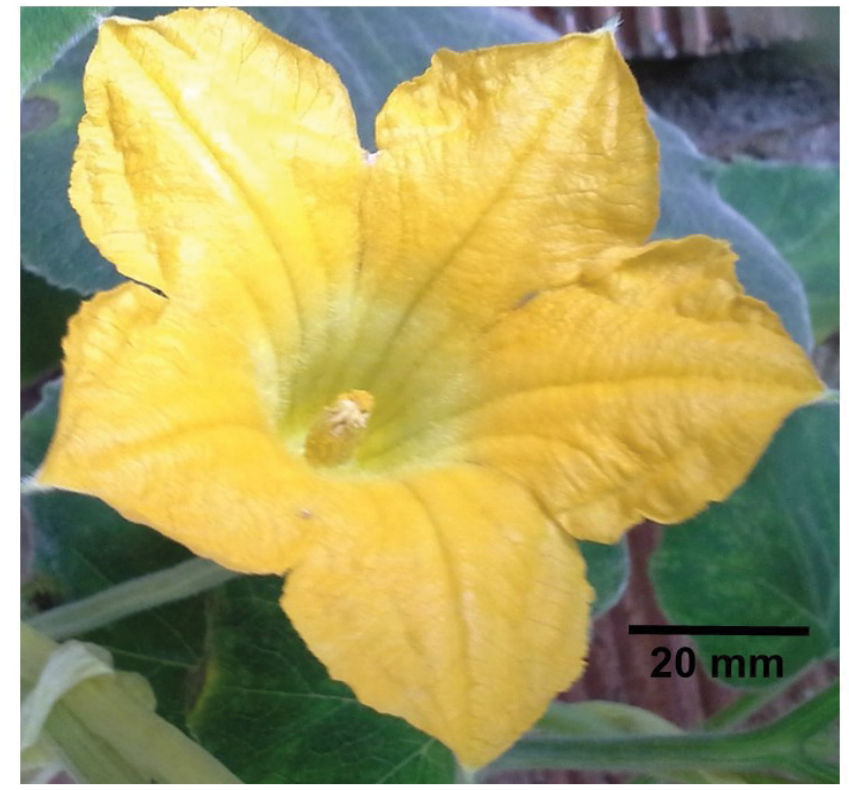

Figure 2: Male flowers of Cucurbira moschata Duchesne (Loche) grown in the Dutch Bucket System. No female flowers buds were observed.
Marketable "Loche" squash is reproduced vegetative only and when reproduced by seeds, fruits acquire "Zapallo criollo" characteristics through generations [7] whose organoleptic properties are not those of "Loche"; in conventional agriculture seeding is accompanied by the application of some biocide powder directly to vine cuts [8], nevertheless, infestations by some common fungi and bacteria for cucurbits are still observed $[8,29]$, some of which were responsible for a low percentage (16\%) of selected seedlings suitable for transplanting. Aqueous nutrient solutions during sampling and lack of biocide compounds could have favor growth of such microorganisms. Viral symptoms were observed in adult plants even though seedlings were thought to be disease free, a problem also observed in land fields of "Loche" cultivars [6].

Hydroponic "Loche" plants long inter-nodal stems architecture upwards resembles those of a plant grown in a high temperature environment, phenomena observed in Arabidopsis thaliana [30]; moreover, increase diameter of leaves might increase leaf cooling capacity, both adaptations in a well-watered environment. During the pre-experimental treatment, temperature measurements $\left(25^{\circ} \mathrm{C}-30^{\circ} \mathrm{C}\right)$ were above Loche's optimum $\left(18^{\circ} \mathrm{C}-20^{\circ} \mathrm{C}\right)$ which indicates that "loche" plants were in a high temperature environment but with proper water and nutrients supply. High Temperature is also reported to affect female/male flowering ratio in cucurbits [31] and "Loche" [6-8] which can explain the no appearance of female flowering structures.

Temperature can be monitored and controlled in close systems, often used for hydroponic crop production, being investment relatively high to this regard [19]; a completely isolated system as for organic vegetable production [22] with artificial lighting of determined wavelengths could be tested in the long future. However, flowering and its ratio can me modulates by phytohormones in cucurbits [32] which could be tested as a cheaper alternative. Future attempts in hydroponic "Loche" production should consider external application of ethylene or ethylene-releasing compounds in well-stablished transplants as for melon [33] and cucumber [34] and/or direct modulation of any of the genes involved in sex determination for cucurbits already identified $[35,36]$. The former only probable if the parthenocarpic origin of the fruit is validated [6] since no male flowers might be obtained.

Temperature effects in "Loche" has not been studied at the physiological and genetic levels to understand why this particular cucurbit is that sensible to temperature variations, even so that mother plants stocks have to be kept for each farming season and farmers exchange their vine cuts only locally [6,7], which implies a microclimate influence for an optimum production of desirable "Loche". Furthermore, Climate is changing along with global increasing temperature [37], which can endanger "Loche" production. Although, plant adaptations are diverse and involve a complete set of gene expression and equilibrium in enzymatic activity $[38,39]$, they have not been studied comprehensively for this cultivar either. Finally, data reveals no consensus for the origin of the genetic pool of "Loche" cultivars, phenomena which will require further research, but it can be stated that its architecture and metabolism are adapted to a droughtlike environment and that this regional human-driven adaptation could have produced. The "Loche" with the flavor highly appreciated in Peruvian cuisine. Marketable hydroponic "Loche" should meet such organoleptic properties.

\section{Conclusion}

Cucurbita moschata Duchesne "Loche" was stablished in the Dutch bucket hydroponic system, technique no previously described for this 
Citation: Vásquez EF, Vásquez DA (2017) A Preliminary Study for Cucurbita moschata Duchesne (Loche) Crop Production under the Hydroponic Dutch Bucket System. Agrotechnology 6: 173. doi: 10.4172/2168-9881.1000173

Page 4 of 4

crop. "Loche" hydroponic vine structure resembles those of plant being grown in a high temperature environment with constant water supply. Further research on this adaptation is needed to obtain female flowering and fruits through hydroponic technology.

\section{Acknowledgments}

We express our gratitude to Asociación "Llacta Maki" executives for the logistic in the development of this new line of research for "Loche" crop and to Plant Tissue Culture and Phytogenetic Resources Executives of Universidad Nacional "Pedro Ruiz Gallo" (Lambayeque-Perú) whose training allowed the idea conception and evolvement.

\section{References}

1. INDECOPI (2010) Resolution No 018799-2010/DSD-INDECOPI, Lima, Perú.

2. Fernández AM, Rodríguez FE (2007) Ethnobotany of pre-Hispanic Peru. Herbarium Truxillense (HUT), National University of Trujillo, Peru.

3. Llatas S (2005) Phanerogamic Botany. National University "Pedro Ruiz Gallo", Lambayeque, Peru.

4. Jeffrey C (1980) A review of the Cucurbitaceae. Botanical Journal of the Linnean Society 81: 233-247.

5. Deyo A, O'Malley B (2008) Food for thought: The science, culture, and Politics of food.

6. Andres TC, Ugás R, Bustamante $F$ (2006) "Loche": A unique pre-columbian squash locally grown in north coastal Perú. Cucurbitaceae: 333-340.

7. Vásquez L (2016) El "Loche" producto emblemático de Lambayeque.

8. CARITAS DEL PERU (2012) "Loche" of Lambayeque: Cultivation Manual. Impactum Creativos, Lima, Peru.

9. Delgado-Paredes GE, Rojas-Idrogo C, Sencie-Tarazona A, Vásquez-Núñez L (2014) Characterization of fruits and seeds of some Cucurbitaceae in the North of Peru. Fitotecnia Mex Magazine 37: 7-20.

10. CARITAS DEL PERU (2012) Recipe: "Loche" de Oro. Impactum Creativos Lima, Peru.

11. Arbizu C, Blas R, Ugás R (2010) Genetic diversity of "Loche" (Cucurvita moschata Duchesne ex Lam.) Cultivated in Lambayeque, Peru assessed with SSR markers. Proceedings of First Peruvian Congress on Breeding and Agricultural Biotechnology.

12. Campos CE (2009) Characterization of the morphological and molecular diversity (DNA) of Cucurbita maxima Duch C. moschata Duch and C. Pepo L. of the Lambayeque Region. (PhD thesis in Environmental Sciences). National University of Trujillo, Graduate School, Doctorate in Environmental Sciences, Trujillo, Peru.

13. Vidaure-Ruiz JM, Castañeda-Muñoz JS (2014) Determination of heat transfer parameters during the heating of the "Loche" (Cucurbita moschata Duchesne) using numerical and analytical solutions. Engineering Magazine: Science, Technology and Innovation 1: 94-105.

14. Delahaut AK, Newenhouse CA (1998) Growing pumpkins and other vine crops in Wisconsin: A guide for fresh-market growers. University of Wisconsinsystem Board of Regents and University of Wisconsin-Extension, Cooperative Extension.

15. Napier T (2009) Pumpkin production. PRIMEFACT 964: 1-8.

16. Bratsch A (2009) Pumpkins. Virginia State University, Virginia Cooperative Extension Publication, USA.

17. IDIAP (2003) Guide for integrated management of squash cultivation. Agricultural Research Institute of Panama, Panama.

18. Drost $D$ (2011) The production of Summer squash inside the high tunnel. Utath State University Cooperative Extension, Hortiulture. USES.
19. Muñoz H (2010) Hydroponics Manual: Home-based vegetable production system. Inter-American Institute for Cooperation on Agriculture, Guyana.

20. Kratky BA (2004) A suspended pot, non-circulating Hydroponic method Proceedings of the South Pacific Culture Conference. Acta Hort 648: 83-89.

21. Roberto K (2004) How to Hydroponics. The Futuregarden Press, $4^{\text {th }}$ edn, New York, USA.

22. Wright $P$ (2004) Totally organic Hydroponics, $1^{\text {st }}$ edn, N.C. Winters and Quie Graphics.

23. Asao T (2012) Hydroponics: A standard methodology for plant biological researches. In Tech Croatia.

24. Fita A, Postma J, Picó B, Nuez F, Lynch J (2008) Root architecture variations in Cucurbita. Proceedings of the IXth EUCARPIA meeting on genetics and breeding of Cucurbitaceae, INRA.

25. Wang L, Yang X, Ren Z, Wang X (2014) The co-involvement of light and air temperature in regulation of sex expression in Monoecious cucumber (Cucumis sativus L.). Agricultural Sciences 5: 858-863.

26. Trejo-Téllez LI, Gómez-Merino FC (2012) Nutrient solutions for hydroponic Systems. Hydroponics: A standard methodology for plant biological researches. In Tech, Croatia.

27. IBM Corp (2010) IBM SPSS Statistics for Windows, Version 19.0. Armonk, NY IBM Corp.

28. ACES (2004) Plant Disease Notes, Mosaic viruses in cucurbits. Alabama Cooperative Extension System, USA.

29. UKCES (2009) An IMP scouting guide for common problems in Cucurbit crops in Kentucky. University of Kentucky Cooperative Extension Service, USA.

30. Crawford AJ, McLachlan DH, Hetherington AM, Franklin KA (2012) High temperature exposure increases plant cooling capacity. Current Biology 22 396-397.

31. Kumari M, Singh HS, Behera TK (2016) Flowering and its modification in Cucurbits. Handbook of Cucurbits: Growth, cultural practices and Physiology. CRC Press, Arizona, USA.

32. Abdel-Rahman M (1970) Modification of flowering, sex expression and fruiting of selected cucurbits by growth-regulating chemicals. Graduate council of the University of Florida, University of Florida. USA.

33. Byers RE, Baker LR, Herner RC, Dilley DR (1972) Ethylene: A natural regulator of sex expression of Cucumis melo L. Proceedings of the National Academy of Sciences 69: 717-720.

34. Wang D, Li F, Duan Q, Han T, Xu Z, et al. (2010) Ethylene perception is involved in female cucumber flower development. The Plant Journal 61: 862-872.

35. Kater MM, Franken J, Carney KJ, Colombo L, Angenent GC (2001) Sex determination in the monoecious species cucumber is confined to specific floral whorls. The Plant Cell 13: 481-493.

36. Saito S, Fujii N, Miyazawa Y, Yamasaki S, Matsuura S, et al. (2007) Correlation between development of female flower buds and expression of the CS-ACS2 gene in cucumber plants. Journal of Experimental Botany 58: 2897-2907.

37. Steffen W, Richadson K, Rockstrom J, Cornell SE, Fetzer I, et al. (2015) Planetary boundaries: Guiding human development on a changing planet Sciencexpress.

38. Kirschbaum MUF (2004) Direct and Indirect climate changes effects on photosynthesis and transpiration. Plant Biology 6: 242-253.

39. Zróbek-Sokolnik A (2012) Environmental adaptations and stress tolerance of plants in the era of climate change. Springer Science+Business Media LLC New York, USA. 